\title{
Die Rede van Stefanus in Openbaringshistories Perspektief
}

\section{DIE KARAKTER VAN DIE REDE VAN STEFANU IS}

Die rede van Stefanus voor die Joodse Raad in Handelinge 7 is van besonder groot belang. want in hierdie rede gee Stefanus vir ons in stuk openbaringsgeskiedenis van die OT. En 'n besondere kenmerk is dan dat ons hier die openbaringsgeskiedenis van die O.T. kry vanuil Pinkster.

Die rede van Sefanus is deur die evangelis l ukas opgeneen in die Handelinge van die Apostels.

l.ukas beskrywe in sy tweede boek die voortgang van die Evangelie vanuit Jerusalen na Judéa en Samaria tot aan die uiterste van die aarde (Hand. 1. 8). In die boek Handelinge vind ons verskillende redevoeringe nl. drie van Petrus, cen van Stefanus en sewe van Paulus. Wanneer ons $k y k$ na die plek van die verskillende redevoeringe in die Handelinge. dan sal dit ons tref dat lukas al daardie redevoeringe gebruik as materiaal om die gebeurtenis van sy verhaal nader te verklaar. Al daardie redevoeringe is deur lukas in sy boek opgeneem on die gebeurtenisse van sy verhaal te karakteriseer en te illustreer. ${ }^{1}$

(i. Stählin noem die rede van Stefanus in merkbaken wat dic groot wending in die openbaringsgeskiedenis wil aangee." Die Koninkryk van God is in sy uitbreiding besig om oor die grens te gaan van Jerusalem na Judéa en Samaria en daarom gaan lukas deur middel van Stefanus se rede aangee op watter grond hierdie grensoorskryding plaas vind.

Teenoor $M$. Dibelius wat die redevoerings in die Handelinge wel beskou as toeligtings op historiese situasies, maar hulle self nie as histories wil erken nie. ondat hulle net beskou moet word as vrye komposisies van l.ukas self, ${ }^{3}$ wil ons die historiese karakter van al die redevoerings in die Handelinge en dus ook die van Stefanus onderstreep. Ons aanvaar dat Stefanus self hierdie rede uitgespreek het voor die Joodse Raad, maar legelyk erken ons, dat I.ukas ook Stefanus se rede in sy verhaal ingevoeg het on die voortgang van die Evangelie in dic wêreld te skilder.

Vervolgens moet daarop gewys word dat die verskillende redevoeringe in die Handelinge soos $H$. N. Ridderbos dit gestel het. tipiese voorbeclde is van die christelike prediking na Pinkster in die jong Kerk.'

'n Noukeurige analise van die 11 redevoeringe in die Handelinge het aan die lig gebring dat in al daardie rectevoeringe dieselfde elemente lerugkeer.

W. J. Snyman het daarop gewys dat die rede van Stefanus selfs in sy vorm in groot mate van ooreenkoms vertoon met die prediking van 
Petrus. Wat Petrus in sy oudste prediking van Christus verkondig word deur Stefanus met dieselfde woorde van Moses gesê." Hier kom ons al dadelik by die christologiese element in die prediking van Stefanus wat o.a. deur G. Stählin so treffend opgemerk is: wat Stefanus in sy rede van Josef en Moses sê. is gesê om Josef en Moses in hulle lyding as tipes van Christus te teken. ${ }^{\mathrm{T}}$

Hoewel Sefanus sy rede onder besondere omstandighede uitgespreek het. mag ons tog die rede van Stefanus nie isoleer van die prediking van die apostels nie. Ons kan veilig aanneem dat ons in die rede van Stefanus te doen het met in duidelike voorbeeld van die oudste, apostoliese prediking. Grondpatroon van Stefanus se rede is die historiese. apostoliese prediking. al is dit hier dan 'n prediking in ' $n$ besondere situasie.

Wat die vorm betref is die rede van Stefanus 'n ..Streitrede" maar volgens sy inhoud gee hierdie rede volgens E. Stauffer ..ein Durchblick durch die (ieschichte Israels"."

Stefanus gee ons in sy rede maar nie net 'n gedeelte van die Bybelse geskiedenis van die OT nie. maar soos ons later nog sal aantoon. ook die openbaringsgeskiedenis van die OT en dan seer bepaaldelik dic openbaringsgeskiedenis van die OT vanuit die NT, vanuit Pinkster. En dit bring ons al dadelik tot 'n belangrike konklusie: die oudste prediking, die Jerusalense kerugma was openbaringshistories van karakter.

In die oudste prediking van die Kerk van die NT is die OT madr nie net deur die apostels gebruik as bewysmateriaal vir dic waarheid van hulle verkondiging nie, maar die OT het in die prediking van die apostels 'n konstitutiewe betekenis gehad."

Die materiaal van die kerugna aangaande Christus is ontleen aan die OT. In die redevoeringe van Petrus is veral geput uit die profesiei van die OT, terwyl Stefanus sy materiaal vernaamlik gekry het uit die historiese boeke van die OT. Wie Jesus was en wat die betekenis van Sy koms en Sy werk is, het die apostels uit die OT verstaan.

En veral in die rede van Stefanus kom die openbaringshistoriese karakter van die oudste prediking so duidelik na vore.

Die les wat ons hieruit kan leer, is dat ons in ons prediking uit die NT die OT nie moet vergeet nie. Soos ons in die prediking oor oud-testamentiese gedeeltes die lyne deurtrek na die NT. so moet ons ook wanneer ons uit die NT preek die lyne terugtrek tot in die OT.

In die prediking oor nuwe-testamentiese gedeeltes moet die open. baringsgeskiedenis van die OT ook deurklink en dan nie fragmentaries as bewysmateriaal nie, maar as 'n openbaringshistories onderbou volgens die hermeneutiese reël. Novum Testamentum in Vetere latet. Vetus Testamentum in Novo patet.

Hierdeur sal die prediking ongetwyfeld aan diepte en rykdom win. want die openbaring van God in die NT kan net verstaan word as 'n voorsetting en vervulling van wat (iod in die (O) in die geskicdenis van die volk Israel gedoen en deur die profete gespreck het. 


\section{DIE IITGANGSPINI VAN DIE REDE VAN SIEFANIS}

Stefanus gaan in sy rede uit van die heilfeit van die uitstorting van die Heilige (iees. Die groot tema van die Handelinge van die Apostels: (hristus in ons. teenoor die sentrale gedagte van die Evangelies: ons in (hristus (begrepe). vind ons ook in die rede van Stefanus. Daarom val in sy rede die volle aksent op die tempel en die inwoning van God en daarom is die verse $48-50$ die hoogtepunt van hierdie redevoering.

In navolging van E. Sauer het W. J. Snyman die gedagte uitgespreek dat dit met Pinkster gaan on die koms van die Koninkryk van God. ..Die Koninkryk van God het gekom op Pinksterdag. Dit is die sentrale plek van Pinkster in die Openbaringsgeskiedenis van die Nuwe Testament. Sinds Pinkster is daar by al die koninkryke. ook in Koninkryk van (jod. en onder (en uit) alle volkere ook 'n Volk van God, op aarde"."1"

Die koninkryksaspek van Pinkster vind ons reeds in die Evangeliz volgens Iohannes. Die Evangelis Iohannes wys op die openbaringhistoriese betekenis van Pinkster wanneer hy in hoofstuk 7. 39 skrywe: ..Want die (jees was daar nog nic. omdat Jesus nog nie verheerlik was nie"*. Dit mag miskien vreemd klink. want in die OT lees ons dikwels van die Heilige Gees. Voor Pinkster was die Gees daar al. Daar was 'n werking van die Gees in die skepping. in die natuur. Die Gees het gewerk in die harte van mense en hulle gebring tot bekering en geloof. tot boete en berou en tot blydskap in God.

Maar voor Pinkster was die Gees daar nog nie as die Gees van die gekroonde Here Jesus nie. Daar is ' $n$ innige verbinding tussen die verheerliking van Jesus en die uitstorting van die Heilige (jees. Pinkster staan in verband met Christus se verhoging. " Die Heilige Gees wat op Pinkster gekom het is die Gees van die verheerlikte Christus. Daarom noem Petrus die Heilige (jees dan ook die Gees van die heerlikheid. die Gees van die doxa (l Petr. 4.14). Dit beteken dat deur die uitstorting van die Heilige Gees die doxa. die heerlikheid. die koningskap. die heerskappy. die feit dat Jesus nou Kurios. Here is. tot openharing kom.

Daar is 'n noue samehang tussen die feit van Pinkster en die Koninkryk van Ciod. Hemelvaart was die troonbestyging van Koning Jesus en Pinkster is vervolgens die realisering op die aarde van daardie gebeurtenis in die hemel.

Petrus wys in sy Pinksterpreek ook op die koninkryksaspek van Pinkster wanneer hy $s \hat{c}$ dat (hristus die Koning is wat op die troon van Dawid sal gaan sit (Hand. 2. 30). Christus is die Here. die Kurios wat aan die regterhand van (jod sit (Hand. 2. 34).

Jesus sit op die troon in die hemel. Deur Sy Gees daal hy neer na die aarde en gaan ook Jaar sit op die troon. nl. in Sy Kerk. in dic hart van die gelowige. Pinkster is die verwerkliking van die Koninkryh van (iod op aarde. Die ryk van Gol is nou hier. in en op die wyse van die (jees. Dit is 'n Koning wat op Pinkster kom woon in Sy Kerk.

In die ()) het (jorl as Koning gewoon onder Sy volk. In die NT woon Christus as Koning in Sy volk. 
Ons sal die heilsfeit van Pinkster dan eers goed verstaan wanneer ons die verband sien tussen die hegrippe Kurios, pneuna. en doxa. '" Die doxa is aan Christus as die Kurios verhonde -. ons sal dit later nog duidelik sien - en die (jees is die Bewerker van die doxa (verg. Ef. 3. 16; 1 Petr. 4, 14) ${ }^{13}$

Die koms en ' $n$ inwoning van 'n Koning is die uitgangspunt van die rede van Stefanus. Ons vind dit al dadelik in sy eerste woorde. wanneer hy daarop wys, dat die (joll van die heerlikheid aan Abraham verskyn het(7, 2). Die God wat as die God van die doxa aangedui word. het volgens Stefanus gaan woon onder die volk Israel.

Uitgangspunt van Stefanus se rede is die besondere benaning van (jod as die God van die doxa.

Ons kry hier 'n aanhaling uit die OT en wel uit Psalm 29. Stefanus het vir sy aanhaling gebruik gemaakt van die Septuaginta. Ons kan hier nie op die probleme wat saamhang met die gebruik van die I.XX deur die nuwetestementiese skrywers ingaan nie." maar omdat die I.XX so dikwels in die NT aangehaal word, sal dit goed wees om te luister na die raad van E. Stauffer om by die uitleg van die NT die Septuaginta maar te gebruik."

Stefanus noem Jahwe hier die (iod van die doxa. Doxa is in Griekse woord wat eintlek ,.mening" beteken. Hier word egter dic woord doxa gebruik soos dit in die I.XX aangewend word nl. as die Griekse vertaling van die Hebrecuse kabood." Kabood betcken let. terlik ..gewig. gewigtigheid" (vai) 'n werkwoord wat ..swaar wees" beteken) en ons vertaal dit dikwels met: majesteit. heerlikheid. luister en dergelike woorde.

Die woord doxa in die NT is deur die Hebreeuse kabool bein. vloed en word daarom gebruik vir belangrike persoonlikhedeli en is ook nou verbonde met woorde soos basileia en dunamis."

Met die doxa van God word bedoel die indrukwekkende majesteit van Jahwe. Die regte betekenis van hierdie woord wat Stefanus gebruik. sal log eers vir ons duidelik word. wanneer ons bedink. dat doxa ook 'n Griekse ekwivalent is vir die Hebreeuse word Sjckhina. "n begrip wat ons aantref in verskillende Targums en die rabbynse teologie. Dic woord Sjekhina kom van "n werkwoord wat ..om te woon" beteken en is deur die rabbyne ontwerp om dic goddelike teenwoordigheid en die Heilige (iees aan te dui."' Dic Sjekhina is dic joolse uitdrukking van die goddelike majesteit met 'n reddende en 'n destruktiewe aspek. verlossend vir die volk en oordelend, straffend oor die vyande."

Stefanus begin dus sy rede met te sî dat Jahwe Hom in sy uit. stralende heerlikheid en majesteit aan Abraham geopenbaar het. (Ons kan daarom Hand. 7, 2 so omskrywe: Cod het Hom in Sy koninklike majesteit aan Abraham geopenbaar. In hierdie lig moet ons Stefanus se spreke oor die tempel verstaun. Die doxa van (joxl, die Sjokhina van Jahwe was in die OT aan die tempel verbonde. Die tabernakel van Moses en die tempel van Salomo was met die heerlikheidl. die doxa van God vervul d.w.s. die Sjekhina van Jahwe was teenwoordig in die tabernakel en tempel of om dit nog noukeuriger uit te druk: Jahwe 
was Self in Sy koninklike majesteit in daardie tabernakel en tempel aanwesig (verg. Ex. 40. 34 en I Kon. 8. 1()-11).

Die Jole het egter gedink dat die besit van die tabernakel en die tempel vanself ook die teenwoordigheid van Jahwe verseker. En daarom is daar die verrassende wending in Stefanus se betoog: die doxa van Jahwe wat in die (OT wel aan die tempel verbonde was. kan $10 \mathrm{~g}$ nie met die tempel vereenselwig word nie. want die doxa was al met Abraham voordat die tabernakel of dic tempel gebou was en die doxa was ook met Josef. Moses. Dawid en Salomo.

Stefanus kon sy rede nie heeltemaal tot 'n einde bring nie. maar uit wat hy gesê het. is tog duidelik. dat hy wou aantoon. dat die doxa van (iod nou nie meer aan die tempel verbonde is nie maar aan die persoon van Jesus Christus.

En dit word nog bevestig deur die woorde van Lukas wat in vs. 55 beskryf hoe Stefanus sy oe na die hemel hou en die heerlikheid (die doxa) van God sien en lesus wat staan aan die regterhand van God.

Die woordjie ..en" in hierdie teks is "n verklarende ..en" ('n s.g. kai-epexegeticus). .1

Ons kan dus die woorde van lukas soos volg vertaal: Stefanus sien die heerlikheid. die doxa van God. nl. Jesus.

Die heerlikheid van God is nou ten volle gebind aan Jesus Christus. Jesus staan daar in die hemel soos 'n Koning, mel koninklike majesteit.

\section{DIE AANSI UITING AAN DIE PROFEET ESEGIÏI EN DIE EVANGEI.IE VOI.GENS JOHANNES}

Openbaringshistories gesien kry ons hier in die rede van Stefanus 'n direkte aansluiting met die profeet Eségiel en met die Evangelie volgens Johannes. In die rede van Stefanus word die tempelgedagte baic seniraal gestel. want Stefanus word daarvan beskuldig dat hy teen die tempel lasterlike dinge gepraat het (Hand. 6, 13). Jesus die Nasaréner sal die tempel afbreek (Hand. 6, 14). Hoewel in Stefanus se rede dic volle aksent val op die tempel as die woning van Jahue. beklemtoon Stefanus log die betreklikheid van die tempel as woning van Goxl.

Teenoor die verabsolutering van die tempel deur die Jode stel Stefanus die tydelike en beperkte bedoeling van God met die tempel Die diens van (iod is nie aan die tempel gebonde nie.

In die ()T het die profeet Escégiël reeds geleer dat die Sj*khina en die tempel nie onafskeidelik aan mekaar verbonde is nie.

Nêrens word in die Bybel die doxa van Jahwe uitvoeriger en beeldryker bexkryf as deur die profeet Eségiël. In sy profesieé staan die tempelgedagte ook baie sentraal. Eségiel teken in sy eerste hoofstuk ..Yahweh riding on his cherubimthrone".:- Die profeet sien "n gestalte van in troon (1.26 en lahwe sit op daardie troon wat gedra word deur vleuels van cherubyne $(1,9)$ en daar is wiele naas die vlerke (1. 19) Die Sjekhina van Jahwe, die doxa van (jod word hier visionêr voorge. stel met die beeld van in troonwa soos $H$ Veldkamp dit is sy hoch: De balling van de Kabaroe so treffend beskryf.:-3 
In die tiencle hoofstuk teken die profeet Eségiël hoe die Sjckhina die doxa van God, soos die I XX dit sè. die tempel gaan verlaat. En daardie onttrekking van die doxa van (iol aan die tempel is in gevolg van die sonde van die volk. die sonde met die tempel en die sonde in die tempel soos dit in hoofstuk nege beskryf word.

En in hoofstuk 43 teken die profeel hoe die doxa van Jahwe weer intrek neem in die nuwe tempel. Die profeet Eségiël wil ons leer. dat ..de heerlijkheid van Jahwe onafhankelijker van de omgeving gedacht wordt; ze kan tent en tempel verlaten en verschijnen zelfs in het heidenland".:-"

By hierdie gedagte van Eségiël sluit die evangelis Johannes hom aan. Ook in die Evangelie volgens Johannes staan die tempel-gedagte baie sentraal. Reeds in sy proloog laat Johannes sy lesers sien dat die doxa van God nie meer aan die tempel gebonde is nie maar aan die geinkarneerde Logos: ,En die Woord hei vlees geword en het onder ons gewoon (letterlik: sy tent opgeslaan) - en ons het sy doxa gesien. "n doxa soos van die Eniggeborene wat van die Vader kom" (l. 14)."

Ook Jesus se antwoord aan Natánael in 1, 52 waarin Hy verwys na die droom van Jakob en die engele van (joxl wat opklim en neerdaal. openbaar, dat die brug tussen hemel en aarde nie langer gebonde is aan ' $n$ bepaakle plek( 'n steen of ' $n$ gehoul nie maar aan 'n persoon in wie die doxa van (jod sigbaar geword hel.t.

Die geskiedenis van die tempelreiniging in hoofstuk 2 loop uil op 'n selfopenbaring van Jesus waarin $\mathrm{Hy}$ oor die afbraak van die tempel praat (2. 19) en daarmee verwys na die tempel van Sy eie liggaam (2. 21). Die evangelis Johannes het die tempelreiniging gesien as 'n teken dat die tempeldiens vervang sal word deur die verering van die persoon van Christus wat sal sterf en opstaan (2. 22).

En in hoofstuk 4 lees ons dat die ware tempelkultus die aanhidding in gees en waarheid is (vs. 23).

Johannes verbind in sy evangelie-verhaal die doxa van God aan die persoon van Jesus Christus en dan is dit besonder opvallend, dat Iohannes die doxa in verbinding bring met die kruis van (hristus. In hoofstuk 13, 31 skrwye hy: ..En toe hy (d i. Judas. Fl.) buite was. sê Jesus: Nou is die Seun van die mens verheerlik. en (joxl is in Hom verheerlik". ..Die verheerlijking valt in het Johannesevangelie samen met het kruis. Want dat is het culminatiepunt van Jesus' verheerlijking van (iod en daarmee het begin van zijn verheerlijking door Gol". "By hierdie gedagte van Eségiel en Johannes het Stefanus hom in sy optrete en prediking baie nou aangexluit.

Daar was by die jong Kerk in die begin van die Handelinge van die Apostels nog in sterk binding aan die tempel en die Joodse erediens. Die apostel Petrus en Johannes gaan nog na die tempel om daar Cind te aanbied (Hand. 3. I) en ook die gelowiges het die band met die tempel onderhou, want dag vir dag het hulle eendragtig volhard in die tempel (Hand. 2. 46). Die gemeente kom saam in die pilaargang van Salomo (Hand. 5, 12). Die apostels was Palestynse Jode. Hulle was die mense van die tempel. Stefanus het behoort tot die (irickssprekende Jode en hulle was die mense van die sinagoge. 
Stefanus het sterker as ander predikers in daardie tyd die konse$k$ wensies getrek uit die verwerping van Christus as die Messias deur die Joodse volk. Die Sjekhina. die doxa van (jokl is nie meer aan die tempel gebonde nie. En hy het skerp ingesien dat die tempeldiens en die wetsbetragting van die Jole ' $n$ verset is teen die Heilige Gees (Hand. 7.51).

Stefanus het teenoor die Jode nie die tempel en die wet in hulle goldelike orsprong aangeval nie. maar teenoor die Jode wou hy die beperkte en tydelike bedoeling van Gol met Sy tempel en Sy wet aantoon."-

Helder het Stefanus deursien dat die gemeente van die NT geroep is tot ' $n$ ander lewe en dat die tyd van die skaduwees verby is.

\section{DIE VERSET TEEN DIE HEII.IGE GEES.}

Die sonde van die Joolse volk karakteriseer Stefanus in sy rede as 'n weerstaan van die Heilige Gees (vs. 51). Die Heilige (iees het gespreek in die profete en na hulle het die vaders nie geluister nie (Calvyn). Die rede van Stefanus dien om vanuit die geskiedenis van Israel die Jokle te wys op hulle sonde. want die sonde van die vaders (vss. 9. 25. 39 en 43) is ook die sonde van die kinders (vs 51 ).

Die sonde van die volk dwars deur die geskiedenis was verabso. lutering van die gawes van Jahw:. God het die volk 'n erfdeel. in land (vs. 3). 'n wet (vs. 38) en 'n tempel (vs. 47) gegee. Die land as 'n gawe van (jocl en die wet en die tempel as media van Ciod se openbaring het egter by die volk meer en meer die plek van God ingeneen. Die volk Israel het volgens die woorde van Calvyn hom net aan die viterlike sinbole geheg en hulle so tot afgode gemaak."

Deur hulle nasionale trots, hulle uiterlike tempeldiens en kasuisliese wetsheskouing het die Jode die deur toegesluit vir die heidene on toe te tree tol die gemeente van die Nuwe Verbond.

En daarom gaan Stefanus in sy rede aantoon dat die Gol van die doxa die land en die volk en die tempel gaan verlaat soos dit reeds leur die profect Eségiël geprofeteer is.

Stefanus sluit hom hier aan by die woorde van Jesus in I.uk. 13. 35: ..Kyk. julle huis word vir julle woes gelaat". Jesus noem in hierdic woorde die tempel as die huis van God: julle huis. .ondat (jod hem niet meer als Zijnen tempel erkent. hem verlaten zal. zoolat hij ophoudt (iods huis le wezen en het huis van menschen wordt, van de Joden"."

Deur sy kragtige en indringende prediking het Stefanus reeds dic grendel afgeskuif van die deur wat nog geslote was na die heidene en nou gaan hy in sy rede voor die Joolse Raad aantoon waarom Gol so handel.

(ionl se openbaring. so verduidelik Stefanus. is nie gebonde aan die land en die volk van Israel nie en daarom mag (jol se openbaring ook nie tot die volk Israel beperk bly nie.

En daarom beklemtoon Stefanus in sy rede dat die groot openbaringsdade van Jahwe buite die grense van die Ioolse land plaas gevind het. Die llere het Ilom an Abraham geopenbaar loe hy nog in 
Mesopolamie was (vs. 2) en (iod hel llom aan Moses geopenbaar in Egipte en in die woestyn (vss. 30 en 38).

Hier kry ons openbaringshistories gesien 'n noue aansluiting van Stefanus se rede aan die prediking van Jesus in dic sinagoge te Nasaret waar Jesus ook daarop wys dat twee openbaringsdade van God in die OT plaas gevind het buite die grense van die land Kanaän nl. die openbaring aan 'n weduwee te Sarfat in Sidon en die openbaring aan Naäman die Siriër (Luk. 4. 25-27).

Wat die Jode met die land gedoen het. het hulle ook met die wet gedoen. Hulle het die lewende woorde ontvang (vs. 38). hulle het die wet deur die beskikking van engele ontvang (vs. 53), maar die vaders wou nie luister nie (vs. 39) en ook die kinders wou nie die wet onderhou nie (vs. 53). Hulle het die wet vergoddelik soos die land en die volk.

En met die tempel was dit dieself de. Jahwe het onder Sy volk gaan woon; eers in die tent(vs.44) en later in die tempel (vs. 47), maar die tempel het hulle verabsoluteer en vergoddelik.

In plaas van in die tempel Jahwe te dien het hulle, so sê Stefanus. die tent van Molog opgeneen (vs. 43). Hier bring Stefanus ons by die karikatuur van Pinkster. Molog. in heidense afgod woon onder die volk Israel.

Stefanus teken uitvoerig in sy rede die verskillende afgode van die volk Israel: die goue kalf (vs. 41). die leër van die hemel (vs.42). Molog en Renfan (vs. 43). Dit is die eksterne afgode. Daarby kom dan ook die interne afgode: die land. die wet en die tempel.

En die diepste oorsaak van Israel se afgodery ook met land, wet en tempel noem Stefanus in vs 39: die vaders het met hulle harte na Egipte teruggekeer. Daarom is daar by die Joodse volk in hulle geskiedenis ' $n$ tradisie van afval ondanks die feit dat die (iol van Abraham. Isak en Jakob lewende woorde aan hulle gegee het.

Volgens Stefanus het die volk Israel nooit wesenlik uit Egipte ge. trek. Hoewel hulle met hulle voete Egipte verlaat het. het hulle met hul harte in daardie land gebly.

Hier lê die oorsaak, dat die vaders Moses verstont het (vs. 39) ^n soos die vaders nie na Moses wou luister nie. so wou ook die kinders nie na die woorde van Jesus, die Regverdige luister nie (vs. 52). Dic profete is vervolg en Jesus is gedool. ondat die hart van die volk in Egipte gebly het.

In Stefanus se spreke orr Egipte kry ons 'n duidelike voorbeeld van die verskil tussen Bybelse geskiedenis en openbaringsgeskiedenis. In sy rede gee Stefanus 'n gedeelte van die Bybelse geskiedenis van die ()! maar hy behandel dit openbaringshistories. In die Bybelse geskiedenis gaan dit oor die feite en in die openbaringsgeskiedenis handel dit oor die openbaring van God in en deur daardie feite. Ons moet wel oppas om nie 'n teenstelling te maak lussen Bybelse geskiedenis en openbaringsgeskiedenis nie. want dit is verkeerd on te dink dat dit in die Bybelse geskiedenis net gaan om die feite en in die openbaringsgeskiedenis net on die interpretasie van daardie feite. In die openbaringsgeskiedenis gaan dit sowel om dic feite as ook om die interpre- 
tasic van daardie feite. sowel om gebeurlenisse as ook om die waarheidsinhoud van daardie gebeurtenisse.

Wanneer Stefanus openbaringshistories oor Egipte gaan spreek dan is dit nie in " $n$ moderne sin soos byvoorbeeld by $R$. Bultmann wat 'n teenstelling skep tussen ...jeschichte" en ..Heilsgeschichte" ondat die historisering van die geloof in stryd sou wees met sy vertikaal. eksi. stensiële karakter nie.:i

Wanneer Stefanus openbaringshistories oor Egipte gaan spreck dan beluister ons is sy rede 'n spiritualisering. 'n vergeesteliking van Egipte. Geografies is Egipte 'n land by die Nyl. maar openbaringshistories is Egipte ook die tuiste van die ongelowiges, die ongehoorsames. Hierdie proses van spiritualisering van Egipte het al begin by die profeet Hosea ${ }^{3:-}$ en dit kan deurgetrek word tot die Openbaring van Johannes waar die stad Jerusalem waar Jesus gekruisig is geestelik genoem word Solom en Egipte (11.8). Opsetlik spreek Johannes hier nie meer van Jerusalem nie. Die naam Jerusalen reserveer hy vir die Godstad wat hy verwag. Wanneer die aardse Jerusalem ongehoorsaam is, dan word hy nie meer Jerusalem genoen nie maar Sodom en Egipte.

Egipte is die geestelike tuiste van almal wat die Woord van God ongehoorsaam is en Christus as die Regverdige verwerp.

Stefanus toon hier aan dat die godsdiens in watter vorm ook al 'n saak is van die hart (vs. 39) en hy kwalifiseer die afgodery in watter vorm dit ook al geoefen word as 'n weerstaan van die Heilige Gees (vs. 51).

in Besondere aspek van hierdie sonde van Israel word nog deur Stefanus geteken in die verse 38 en 39 . Dit is al dadelik opvallend. dat Stefanus hier die volk Israel aandui as in ekklesia. Daar is verskil van gedagte hoe ons die woord ekklesia hier moet verstaan. J. C. Coetzee neem in sy proefskrif: Volk en Godsvolk in die Nuwe Testament aan dat die woord ekklesia hier in in neutrale of profane sin gebruik is in die betekenis van volksvergadering. hoewel hy self tog noet erken dat die woord ekklesia as volksbegrip maar selde in die NT voor kom. ${ }^{3}$ $F$. W. Grosheide en $\mathrm{F}$. I. Bruce is meer ten gunste van die gedagte dat ons hier ekklesia in 'n religieuse sin moet verstaan. Jus as Kerk. ${ }^{3-1}$

Ons wil hier ekklesia ook as Kerk verstaan. ondat daar anders so gemaklik 'n teenstelling geskep kan word tussen die volk Israel in die ()I en die Kerk in die NT. Vir die eenheid van die Kerk van die ()I' en van die NT pleit veral die feit. dat die christelike kerk in die $\mathrm{Nl}$ die titel loegeken word van dic oudlestamentiese volk van God is $k$ ehal Jahwe en dat die voorregle en kwaliteit wat die volk Israel geskenk word by die verbondssluiting in dic woestyn in die NT ook op die Kerk van (hristus loegepas word. Petrus noen in sy le brief die Kerk met dieself le woorde waarmee in die ()T die volk lsrael angalui word: "n uitverkore geslag. 'n koninklike priesterdom. in heilige volk (2. 9; vgl. l:x. 19. 6).

Die konklusic is dan ook geregverdig. dat die volk lsrael wal onder Moses uil Egipte trek deur Slefanus in sy rete as "n kerk gekwalifiseer word. 
Stefanus gebruik hier die woord Kerk in verband met die uitdrukking: lewende woorde. Ons moet by die uitdrukking .lewende woorde nie slegs aan die wet of nog beperkter aan die dekaloog dink nie maar in navolging van Calvyn aan die geheel van die prediking van Moses waarin die beloftes van genade ingesluit was wat Christus Self tot inhoud het. ${ }^{3 ;}$

Die verbinding van die woord .ekklesia' met die uitdrukking .lewende woorde' dui volgens F. W. (irosheide darop dat Stefanus hier wil aangee dat ,de oude ekklesia bestond vóor den tabernakel. kon zonder tabernakel, maar niet zonder Woord (jods. Zoo kan de nieuwe ekklesia, Matth. 16:18, zonder tempel. maar niet zonder Woord Gods. Het Woord Gods is hoofdzaak". "36 En dan verwys Grosheide na Rom. 3. 2 waar Paulus skrywe as antwoord op die vraag wat dan die voordeel van die Jood is: .ten eerste tog seker dat aan hulle die woorde van (jod toevertrou is".

Die Woord van God is die belangrikste ook vir die volk Israel. En Israel se sonde is ongeloof. ongehoorsaamheid aan die Woord van God wat deur die mond van die profete gespreek is waarom die profete Jeur die vaders vervolg is (vs. 5l). Wanneer die Woord van (jorl nie gehoorsaam word nie dan word met die ander dinge wat God gegeo het soos die land. die wet en die tempel afgodery bedrywe.

Stefanus teken in sy rede lsrael se sonde as Woordverlating en Jaarom het die volk die profete as draers van die Woord, as verkondigers van die Woord vervolg en daarom is Christus. die Regverdige as die Woord van God wat vlees geword het. deur die volk Israel gedood. (vs. 52).

Die volk Israel wou nie na die Woord van (jod luister nie (vs. 39) maar omdat die volk hom afgewend het van God, het God Hom ook afgewend van die volk, so sê Stefanus in vs. $42 \mathrm{cn}$ hulle oorgegee aan die leèrs van die hemel om die te dien. En waar die Woord van God verlaat word daar wyk die Sjekhina, die doxa, die heerlikheid van God en daar word die gawes van Gol soos land, wet en tempel voorwerpe van afgodiese verering.

Calvyn pas dit in sy kommentaar toe op die Rooms-Katolieke leer van die transubstansiasie. Hulle is hipokriete wat in die wêreld verstrik is en wat God uit die hemel wil neertrek en aangesien hulle niks anders besit as leë tekens (nudas figuras). wil hulle in hulle verbeelding Christus opsluit in brood en wyn. ${ }^{3 i}$

Dit is die groot les uit die redevoering van Stefanus: die geskiedenis, die volk, die Kerk, die liturgie. die sakrament, die kerkorde. die konfessie moet altyd ondergeskik bly aan die Woord van God en mag nooit ten koste van die Woord van (jod verselfstandig word nic. Wanneer die band met God deur ongeloof en ongehoorsaamheid verbreek word, dan gaan land, wet en tempel, priester, fees, besnydenis soos by die Jode die plek van God ingeneen.

Want wanneer al hierdic heerlike dinge verabsoluteer word ten koste van die Woord van (ioll. dan verval ons tot afgolery met dic gawes wat God vir ons gegee het. Sakramentalisme. liturgisme, kerkisme 
is vorme van afgodery wanneer die sakrament, die liturgie. die kerk losgemaak word van die lewende Woord van God en ten koste van die Woord van God verselfstandig word. Calvyn skrywe so treffend in verband met die gevaar dat daar afgodery bedryf word met die middels wat God gee om Hom te dien. dat ons God wat onder sigbare tekens onder ons aanwesig wil wees. $\operatorname{tog}$ op 'n geestelike wyse (spirituali modo) moet soek. ${ }^{3 *}$

\section{DIE AANSIIIIING AAN DIE PREDIKING VAN PAULUS}

Vanuit openbaringshistoriese oogpunt is daar tenslotte ook "in noue aansluiting van Stefanus se rede met die prediking van die apostel Paulus.

Daar is selfs verskillende punte van ooreenkoms tussen die rede van Stefanus en die redevoering van Paulus op die Areópagus in Hand. 17.

Ook in Paulus se bekende rede keer die tempelmotief terug. Byna letterlik gebruik die apostel die woorde van Stefanus uit Hand. 7.48 wanneer hy sî̀ ..Die God wat die wêreld gemaak het en alles wat daar. in is. Hy wat Here van henel en aarde is, woon nie in tempels met hande gemaak nie" (Hand. 17. 24).

Paulus het ook gesien dat die godsdienstigheid van die Atheners verwant is a die van die lode. Daar is net 'n graduele verskil tussen die Jode en die heidene. K. J. Popma skrywe in hierdie verband: ..Er is een traditie van afval in die loodse volk. en dat ontdanks het feit. dat hun de woorden Gods zijn toshetrouwd. Dezelfde traditie van afval is er onder de heidenen, doch in mindere mate. daar hun geen woorden Ciods telkens opnieuw werden toevertrouwd. Gradueel is er verschil: de afval van het Joodse volk is slieper en hardnekkiger. Maar het is in beide gevallen dezelfde traditie. dezelfde verdringing van de waarheid, hetzelfue ten onder houden. Daaron kan Paulus den gedachtengang van Stefanus" rede gebruiken als hij spreekt te Athene"s:

Stefanus stel daarom ook in sy rede die Jode op één lyn met die heidene en hy noem hulle ..onbesnedenes" (vs. 51). In verdanb hiermee skrywe Calvyn. dat die doop in geestelike afwassing is en daarom moet ons tog oppas dat ons nie met reg verwyt kan word dat ons die doop nie deelagtig is nie. ondat ons vlees en ons hart met onreinhede besmet is."

Wat betref sy tempelprediking trek Paulus die lyn van Stefanus deur. Die apostel sien die gemeente en ook die indiwiduele gelowige as 'n tempel van (jod (Ef. 2. 21: I kor. 3. 16 en 6. 19).

Die erediens van (iol (Rom. 9. 4) wat eenmaal net die voorreg van die volk Israel was. teken Paulus as in geestelike erediens (Rom. 12. 1) of as 'n erediens van (jod deur die (jees (Fil. 3.3).

Hierlie diens in 'n geestelike tempel is "n voorreg wat nou ook aan die heidene verkondig word. (ielowiges uit Jokle en heidene word saam opgebou tot 'n woning van (jol in die (jees (Iff. 2. 22).

Hierdie diens in in geestelike tempel watar Stefanus en Paulus in hulle prediking op wys het die keikvader Augustinus 'n keer so mooi omskrywe met die volgende woorde: 
.Hom (d.i. God) is ons die diens verskuldig wat in die (jriekse taal latreia (offerdiens) genoem word, hetsy in die sakramente hetsy in ons self. Want ons is almal sy tempel en elk vir ons is sy tempel. Ons hart is as ons dit ophef sy altaar: met Sy eniggebore Seun versoen ons Hom deur die priester; ons slag Hom bloedige offers as ons ten bloede toe vir sy waarheid stry; ons brand vir Hom reukwerk van die soetste wierook as ons voor Sy aangesig in 'n vroom en heilige liefde ontvlam is" 11

\section{SAAMVATIENDE KONKLUSIE}

Wanneer ons ten slotte wil kunı tot in paar saamvattende konhlusies dan kan ons dit so stel:

a. die rede van Stefanus verskaf ons dic draad wat loop dwars deur die openbaringsgeskiedenis van die OT en die NT. In die geskiedenis van die Bybel openbaar God Hom as die Here wat as Koning onder die mense wil woon.

b. Die koninklike majesteit van (jol is saamgetrek in Jesus Chrislus in die openbaring van Gorl aan die mense.

c. God mag in Sy koninklike majesteit nie met Sy gawes vercenselwig word nie.

d. Daar is in wese nie verskil tusen die heidendom en die Joodse ortodoksie wat Christus verwerp het nie.

e. God het Hom nie aan een volk en ook nie aan die tempel gebind nie. In die NT is die erediens van God deur die Gees die voorreg vir alle volkere. Daarom is de rede van Stefanus 'n baie sterk pleitrede vir die sendingsgedagte.

f. Die Kerk kan Egipte word en verval tot heidendom wanneer die Woord van die Here verlaat word en nie meer gehoorsaam word nie.

Wanneer ons vanuit hierdie openbaringshistories perspektiewe dic verskillende onderdele van die rede van Stefanus gaan bestudeer soos die geskiedenis van Abraham, van die aartsvaders, van Josef, van die uittog uit Egipte en die verbondsluiting op die Sinai, van die intog in Kanä̈n en van die bou van die tempel, dan sal ons homileties die lyn ontdek wat vanuit daardie gedeeltes getrek kan word na Christus en dan sal dit ook nie moeilik wees on paraneties daardie lyn deur te trek na die tyd waarin ons lewe nie.

Oor bekende Skrifgedeeltes sal nuwe lıg opgaan en ons sal uitvind dat die rede van Stefanus hom besonder goed leen voor die gemeente in vervolgstowwe te behandel. 'n Tekskeuse uit die rede van Stefanus sal ons in navolging van die apostoliese kerugma dwing tot 'n openbaringshistoriese prediking en dit sal ongetwyfeld wees tot verryking en verdieping van die geloof van die gemeente.

1. HI.OOR.

\section{AAN IEKENINGE}

1. H. N. Ridderbos, The speeches of Peter in the Acis of the Apostels. 1961, p. 5.

2. (i. Stahlin. Dic Apostelgeschichte. 1965. p. 112.

3. W. Dibelius, Aufsätze zur Aporeclgeschichic, 1951, p. 120.

4. H. N. Ridderbos, a.w., p. 7. 
5. ('. H. Dodd. The Apostulic Preaching and its Developments. 1951-7, p. 7 e.v. $\mathrm{Vgl}$. ook: II. N. Ridderbos. Karakler en strukluur van de redevoringen, opgenomen in de Handelingen der Apostelen. art in: Geref. Theol. Tijdschrift. 1934. p. 49-86; $225-244$.

6. W. J. Snyman. Dic uitbreiding lan dic Koninkryk van God (nog nicgepublisecerde klasdiktaal vir na-graadse studie).

7. G. Stăhlin. a.k.. p. 112.

8. E. Stauffer. Iic Theologie des Newen Testaments. 1946. p. 81

9. H. N. Ridderbos. The speeches of Peter in the Acts of the Apostels. 1961. p. 25.

10. W. J. Snyman. Riglyne vir die Openbaringsgeskiedenis van dic Nuwe Testament. in: Die (iouc Kandelaar. 1962. le Jaarg. n. 1, p. 45. Verg. ook E. Sauer: The Triumph of the Crucified. 1966. p. 56: .. This means that Pentecost was .. the inaugural day of the kingdom of God in the full New Testament sense".

11. H. R. Boer. Pentecost and Missions. 1961, p. 172, 3.

12. In sy proefskrif: De leer van de Heilige (jeest bij Abraham Kuyper, 1957. het Dr. W. H. Velema die volgende stelling geplaas: ..XII Het is een grote leemte in het artikel over pneuma. in Killel Theoligisches Wörtenbuch. dat op de relatie pneuma-kúrios niet meer aksent is gelegd". Die Rooms-Katolicke nuwtestementikus I. Herrmann gaan in sy bock: Kyrios und Pneuma. Studien zur (hristologic der paulinischen Hauptbriefe. 1961 uit van 'n volkome identifikasie van die (iees en die verhoogde Christus. Verg. p. 57. II. Berkhof. De leer van de Heilige (jeest. 1964, gaan ook in hicrdie rigting. c.f. p. 27. hoevel hy nog wat reserwes behou: ..Dit is niet een identiteit in alle opzichten". p. 28. J. P. Versteeg het daarop gellys dat ons die verhouding van die (iees tot die verhoogde Christus .. Waarschijnlijk het best benaderen vanuit heilshistorische calegorieen". Het eschatologisch-pneu matisch karakter van de kerk volgens het Nieuwe Testament. art. in Iheologid Reformata. Jaarg. X no, 2, Juni 1967. p. 85, 86.

13. Kiltel. Theol. Wörlerbuch zun NT, II. p. 254, s.v. doxa.

14. Verg. R. Bijlsma. de Septuagınt en de hermeutiek van de Bijhel, in: Woord en wereld. Fesstbudel voor K. H. Miskotte. 1961, p. 102. ..Fr is in de LXX een duidelijke lendens waar te nemen van een locgespitste Messiaanse interpretatic van de Hcbreeuwse tekst. De vertaling van Ehed met pais is daar ecn duidelijk voorbeeld van". p. 111.

15. E. Stauffer. a.w., p. ?.

16. Kitlel, a.art.. p. 245.6.

17. H. G. Lindell. R. Scolt. A (ireek-1.exicon. 1958. p. 444.

18. A. Richardson. An Introduction to the Theology of the New Testament. 1966, p. 64

19. R. E. Clemants. (iod and the Temple. The Idea of the Divine Presence in Ancient Isracl. 1965. p. 126. (). Cullmann. Early Christian Worship. 1966. p. 73.

20. Th. C. Vriezen. Hoofdlijnen der theologie van het Oude Testament. 19663. ค. 255,324

21. F. W. Grovheide. De Handeligen der Apostelen 1, 1942. p. 241.

22. R. E. Clements, a.W.. p. 103. Verg. Michaelis in: TWB VII, p 387. s.v. skenoo.

23. H. Veldkamp, De balling van de Kabaroe, 1956, p. 16-31: 109.

24. A. v. d. Born, Ezechiël. 1954. p. 27.

25. (). Cullmann. I. Opposition contre le Temple de ..Jerusalem", molif commun de la teologie johannique et du monde ambiant. 1959, p. 8 e.1.: 39 e.5.

26. (). Cullmann. Early Christian Worship, 1966, p. 73.

27. H. Berkhof. De mens onderweg. 1460, p. 92

28. A. von Harnack. The Mission and the Expansion of (hristianity, 1961. p. 50)

29. Calvyn op Hand. 7. 49, Ed.A. Tholuck, 1833, p. 137:..Quum externis inem bolis Deus se pracsentent suis fore testatur, ut in medio eorum habitet sursum eos invitat. ut spirituali modo ab ipsis quaeratur".

30. S. Cireijlanus. Het heilig Evangelie naar de bexchrijving van Lucas II, 1941, p. 681 . 
31. Verg. Heinrich Ott, (jeschichte und Heilsgeschichte in der Theologic Rudolf Bultmanns, 1955.

32. R. E. Nixon, The exodus in the New Testament. The Tyndale New Testament Lecture, 1962. p. 9.

33. J. C. Coetzee, Volk en Godsvolk in die Nuwe Testament. 1965, p. 64.

34. F. W. Grosheide. a.w., p. 226: F. F. Bruce, The Acts of the Apostels, 196.5. p. 172 .

35. Calvyn a.w., p. 129: ..Quanquam altius respexit hoc loco Stephanus neque enim de nudis praecept is loquitur, sed totam Mosis doctrinam comprehendit: in qua inclusae gratuitae promissiones, alque adeo Christi ipse, unica hominum vita et salus".

36. F. W. Grosheide. a.w., p. 226.

37. Calvyn. a.w., p. 137: Hypocritae mundo impliciti Deum potius e coelo detrahere volunt. et quum nihil habeant praeter nudas figuras, stolida confidentia inflati secure sibi in peccatis indulgent. Sic hodie in Papatu Christum imaginatione sua includant in pane el vino".

38. Calvyn, a.w., p. 137. Cf. noot 29.

39. K. J. Popma, Eerst de Jood. maar ook de (iriek. 1950. p. 92.

40. Calvyn, a.w., p. 139: ..Ita quum hodie baptismi nostri veritas spiritualis sit ablutio timendum est ne iure nobis obiici possit, nos minime Baptismi essu participes, quia carnem et animain habeamus inquinatas".

41. Aangehaal by O. Noordmans. (jestalte en Geest.. 1955. p. 306-7. 